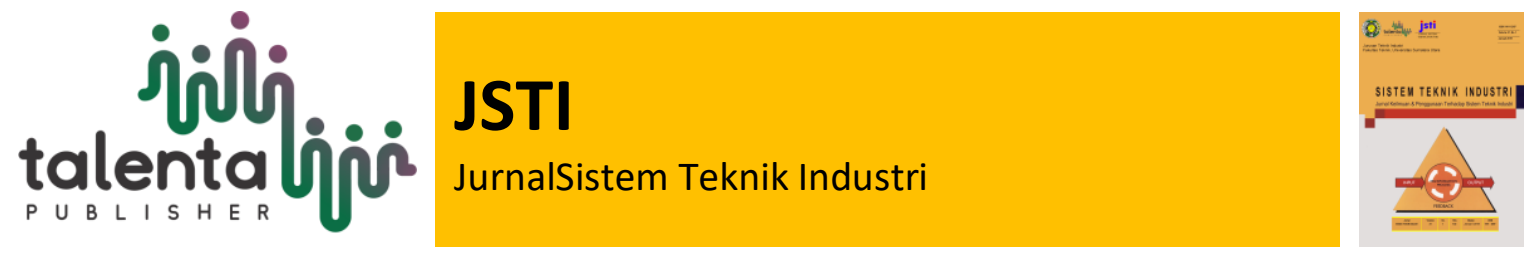

\title{
Identifikasi Limbah pada Proses Produksi Obat Nyamuk Bakar dengan Menggunakan Material Balance
}

\author{
Muhammad Haikal Sitepu, Ulfa Andayani, dan Tania Alda
}

Departemen Teknik Industri, Fakultas Teknik, Universitas Sumatera Utara, Medan, Indonesia

\begin{abstract}
Based on the initial discussion with people form Mosquito coil factory, there is a requirement to calculate the amount of waste from the factory. According to them, several wastes (in the form of liquid and solid waste)are produced inthe process of making mosquito coils. The wastes are often scattered on the floor, causing the condition of the factory space to be unclean or dirty and can cause employees to get sick due to waste scattered on the floor. This research focuses on identifying the waste and to calculate the waste produced by each machine for the production of mosquito coils by using the Material Balance method.Material balance shows a quantitative analysis of material inputs, outputs and wastes / waste at each stage of the production process. Material balance calculation is done in the process of Sifting Coconut Shell Flour, Sifting Process for Coffee Skin Flour, Process for Sifting Wood Flour, Sifting Flour Sifting Process, Onggok Flour Cooking Process, Mixing Material into Mosquito Coe Dough, Mosquito Dough Sifting Process, Forming Process of Paste Paste Plate, The Process of Printing Paste Slabs Into Wet Double Coil, Drying Double Wet Coil Process, Drying and Separation Process of Baking Sheet with Dry Double Coil, Grinding Process of Broken Dry Double Coil, Process of Sifting Sweep Flour Falling on the Floor. Based on the observation, some of the waste obtained from each stage of the production process can be collected again and can be used again as a raw material for making mosquito coils.
\end{abstract}

Keyword:Mosquito Coil, Material Balance, Quantitative Analysis

\begin{abstract}
Abstrak.Berdasarkan diskusi awal dengan pekerja di pabrik obat nyamuk bakar, ada kebutuhan untuk menghitung jumlah limbah yang diproduksi oleh pabrik. Menurut mereka, Limbah tersebut (limbah cair dan padat) diproduksi pada setiap proses produksi pembuatan obat nyamuk bakar. Limbah ini sering tercecer di lantai sehingga menyebabkan keadaan ruang pabrik tidak bersih atau kotor dan dapat menyebabkan para karyawan terkena penyakit akibat limbah yang tercecer di lantai. Penelitian ini berfokus untuk melakukan perhitungan terhadap limbah yang dihasilkan setiap mesin proses produksi obat nyamuk bakar sehingga dapat dilihat seberapa banyak limbah yang dihasilkan dari setiap proses produksi dengan menggunakan material balance. Material balance menunjukkan analisa kuantitatif terhadap material input, output dan wastes/limbah setiap tahapan proses produksi. Perhitungan Material balance dilakukan pada proses Pengayakan Tepung Batok Kelapa, Proses Pengayakan Tepung Kulit Kopi, Proses Pengayakan Tepung Kayu, Proses Pengayakan Tepung Onggok, Proses Pemasakan Tepung Onggok, Proses Pencampuran Bahan Menjadi Adonan Obat Nyamuk, Proses Penghamcuran Adonan Obat Nyamuk, Proses Membentuk Lempengan Pasta, Proses Mencetak Lempengan Pasta Menjadi Double Coil Basah, Proses Pengeringan Double Coil Basah, Proses Penyusunan dan Pemisahan Loyang dengan Double Coil Kering, Proses Menggiling Double Coil Kering yang Patah, Proses Mengayak Tepung Sapuan yang Jatuh Di Lantai. Berdasarkan
\end{abstract}

\footnotetext{
*Corresponding author at:Universitas Sumatera Utara, Medan, 20155, Indonesia

E-mail address:mhd_haikalkarana@usu.ac.id

Copyright (C2020Published by Talenta Publisher, ISSN:1411-5247e-ISSN:2527-9408

Journal Homepage: http://talenta.usu.ac.id/jsti
} 
pengamatan dilapangan didapatkan Sebagian besar limbah produksi dari setiap tahapan proses produksi yang dapat dikumpulkan kembali dan dapat digunakan lagi sebagai bahan pembuatan obat nyamuk bakar.

Kata Kunci:Obat Nyamuk Bakar, Material Balance, Analisis Kuantitatif

Received20 Juni 2020 | Revised27 Juni 2020 | Accepted 29 Juni 2020

\section{Pendahuluan}

Berdasarkan diskusi awal dengan pekerja di pabrik obat nyamuk bakar, ada kebutuhan untuk menghitung jumlah limbah yang diproduksi oleh pabrik. Menurut mereka, Limbah tersebut (limbah cair dan padat) diproduksi pada setiap proses produksi pembuatan obat nyamuk bakar. Limbah ini sering tercecer di lantai sehingga menyebabkan keadaan ruang pabrik tidak bersih atau kotor. Hal tersebut dapat menyebabkan para karyawan terkena penyakit akibat limbah yang tercecer di lantai .Analisis situasi ini difokuskan untuk melihat berapa banyak limbah yang dihasilkan.

Permasalahan yang dihadapi PT. Fumakilla Indonesia adalah banyaknya limbah dari proses pembuatan obat nyamuk bakar, dan pada limbah tepung sangat banyak yang tercecer di lantai. Tindakan yang dilakukan PT. Fumakilla Indonesia untuk mengatasi permasalahan ini adalah mengumpulkan seluruh limbah yang dilantai sehingga dapat digunakan kembali. Namun, tindakan tersebut tidak terlalu efektif karena limbah tersebut akan setiap hari ada di lantai walaupun selalu dikumpulkan karena limbah-limbah tersebut tidak ditampung ketika proses di mesin. Maka dari itu perlu disusun sebuah strategi untuk meminimalisir limbah yang terjatuh dilantai agar dapat meningkatkan produktivitas perusahaan.

Pemecahan terhadap permasalahan di atas dapat dilakukan dengan menggunakan metode Material Balance untuk melakukan perhitungan terhadap limbah yang dihasilkan setiap mesin proses produksi obat nyamuk bakar sehingga dapat dilihat seberapa banyak limbah yang dihasilkan dari setiap proses produksi.

Material balance menunjukkan keseimbangan material yaitu output dan input dalam setiap proses.Adapun rumus untuk kesetimbangan material adalah Total massa masuk $=$ Total massa keluar. Total massa yang masuk yaitu bahan baku, bahan tambahan, sedangkan bahan yang keluar adalah produk yang diinginkan (barang jadi) serta bahan yang hilang (waste)[1].

Model material balance menjelaskan bahwa semua sumberdaya yang diambil dari alam pada akhirnya kembali ke alam juga dalam bentuk limbah[2]. Perhitungan material balance bertujuan untuk mengetahui besarnya jumlah material umpan yang hilang selama kegiatan produksi berlangsung [3]. Perhitungan ini digunakan untuk mencari atau mengetahui material yang masuk (inflow) dan material yang keluar (outflow) pada proses [4]. 


\section{Metodologi Penelitian}

Penelitian ini menggunakan metodologi studi kasus. Jumlah limbah yang dihasilkan oleh proses produksi obat nyamuk bakar menjadi phenomena yang diselidiki pada penelitin ini. Tahapan penelitian ini dibagi kedalam dua tahapan yaitu: tahap observasi dan pengumpulan data dan tahap Analisa data. Pada tahap observasi, penelitian berfokus kepada identifikasi proses, input dan output setiap proses. Kemudian dilanjutkan pada tahap Analisa untuk memvalidkan data input dan output ssetiap proses [5].

\section{Hasil dan Pembahasan}

Material balance menunjukkan analisa kuantitatif terhadap material input, output dan wastes/limbah setiap tahapan proses produksi. Dengan melakukan perhitungan Material balance dapat diketahui jumlah bahan baku yang dapat digunakan kembali dan berapa jumlah limbah yang dibuang [5]. Input material balance dari PT. XYZ dapat dilihat pada Tabel 1.

Tabel 1 Input Material Balance pada PT. XYZ

\begin{tabular}{|c|c|c|c|}
\hline No. & Nama Material & Stasiun & Keterangan \\
\hline 1. & Tepung Batok Kelapa & $\begin{array}{l}\text { Pada semua } \\
\text { stasiun }\end{array}$ & Sebagai bahan baku \\
\hline 2. & Tepung Kulit Kopi & $\begin{array}{l}\text { Pada semua } \\
\text { stasiun }\end{array}$ & Sebagai bahan baku \\
\hline 3. & Tepung Kayu & $\begin{array}{l}\text { Pada semua } \\
\text { stasiun }\end{array}$ & Sebagai bahan baku \\
\hline 4. & Tepung Sagu & $\begin{array}{l}\text { Pada semua } \\
\text { stasiun }\end{array}$ & Sebagai bahan baku \\
\hline 5. & Potasium Nitrat & $\begin{array}{l}\text { Pada semua } \\
\text { stasiun }\end{array}$ & Sebagai bahan baku \\
\hline 6. & IPEL & $\begin{array}{l}\text { Pada semua } \\
\text { stasiun }\end{array}$ & Sebagai bahan baku \\
\hline 7. & Zat Aktif (AI) & $\begin{array}{l}\text { Pada semua } \\
\text { stasiun }\end{array}$ & Sebagai bahan baku \\
\hline 8. & Parfume & $\begin{array}{l}\text { Pada semua } \\
\text { stasiun }\end{array}$ & Sebagai bahan baku \\
\hline 9. & Pewarna & $\begin{array}{l}\text { Pada semua } \\
\text { stasiun }\end{array}$ & Sebagai bahan baku \\
\hline 10. & Emulsifier & $\begin{array}{l}\text { Pada semua } \\
\text { stasiun }\end{array}$ & Sebagai bahan baku \\
\hline 11. & Air & $\begin{array}{l}\text { Stasiun } \\
\text { Stamping }\end{array}$ & Sebagai bahan penolong \\
\hline
\end{tabular}

Sumber : PT. XYZ

Setelah didapatkan data bahan baku yang digunakan dalam proses produksi obat nyamuk bakar maka dapat dilakukan perhitungan material balance pada setiap tahapan proses produksi. 


\subsection{Proses Pengayakan Tepung Batok Kelapa}

Berikut merupakan perhitungan Material Balance pada proses pengayakan tepung batok kelapa.

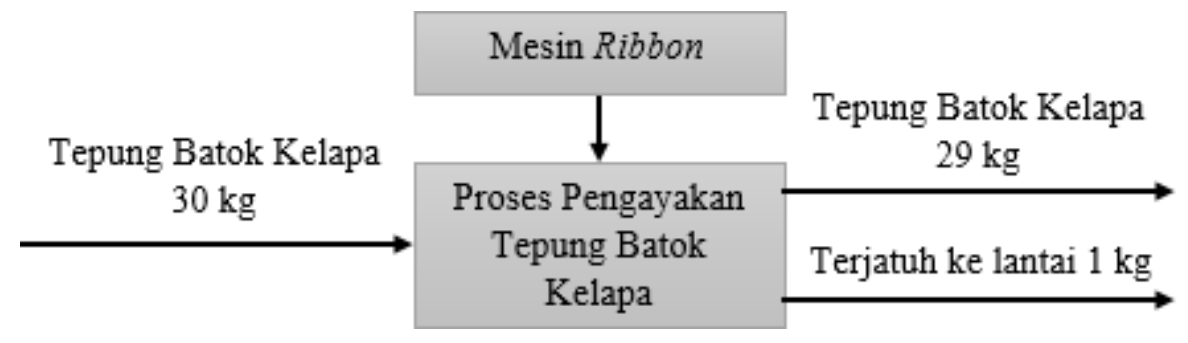

Gambar 1 Proses PengayakanTepung Batok Kelapa

Dari perhitungan di atas dapat dilihat bahwa tepung batok kelapa yang jatuh sebanyak $1 \mathrm{~kg}$ dan tepung batok kelapa yang jatuh tersebut di kumpulkan kembali sehingga dapat digunakan lagi sebagai bahan pembuatan obat nyamuk dengan mengumpulkan lalu mengayak kembali tepung tersebut menggunakan mesin ayak.

\subsection{Proses PengayakanTepung Kulit Kopi}

Berikut merupakan perhitungan Material Balance pada proses pengayakan tepung kulit kopi:

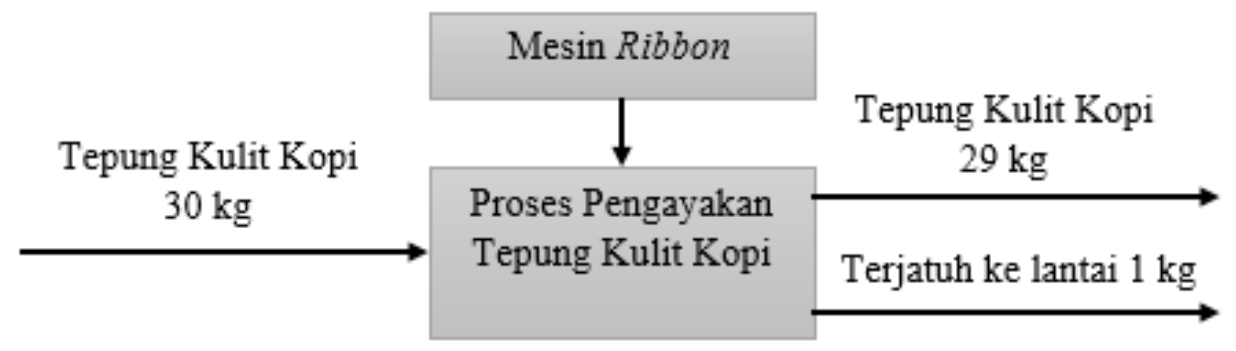

Gambar 2 Proses Pengayakan Tepung Kulit Kopi

Dari perhitungan di atas dapat dilihat bahwa tepung yang jatuh sebanyak $1 \mathrm{~kg}$ dan tepung kulit kopiyang jatuh kelantai tersebut di kumpulkan kembali sehingga dapat digunakan lagi sebagai bahan pembuatan obat nyamuk dengan mengayak kembali tepung tersebut menggunakan mesin ayak.

\subsection{Proses Pengayakan Tepung Kayu}

Berikut merupakan perhitungan Material Balance pada proses pengayakan tepung kayu: 


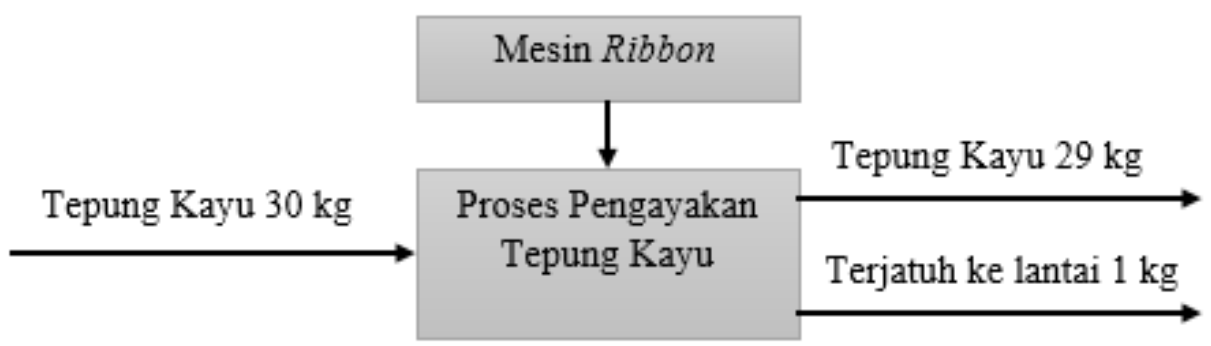

Gambar 3 Proses Pengayakan Tepung Kayu

Dari perhitungan di atas dapat dilihat bahwatepung yang jatuh sebanyak $1 \mathrm{~kg}$ dan tepung kayuyang jatuh tersebut di kumpulkan kembali sehingga dapat digunakan kembali sebagai bahan pembuatan obat nyamuk dengan mengayak kembali tepung tersebut menggunakan mesin ayak.

\subsection{Proses Pengayakan Tepung Onggok}

Berikut merupakan perhitungan Berikut merupakan perhitungan Material Balance pada proses pengayakan tepung onggok:

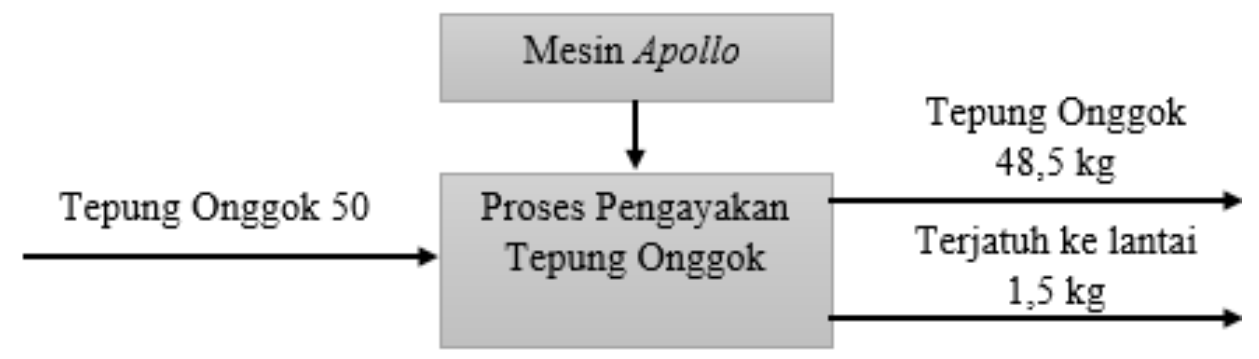

Gambar 4 Proses Pengayakan Tepung Onggok

Dari perhitungan di atas dapat dilihat bahwa tepung onggok yang jatuh ke lantai $1,5 \mathrm{~kg}$ dan tepung onggokyang jatuh tersebut di kumpulkan kembali sehingga dapat digunakan lagi sebagai bahan pembuatan obat nyamuk dengan mengayak kembali tepung tersebut dengan mesin ayak.

\subsection{Proses Pemasakan Tepung Onggok}

Berikut merupakan perhitungan Material Balance pada proses pemasakan tepung onggok: 


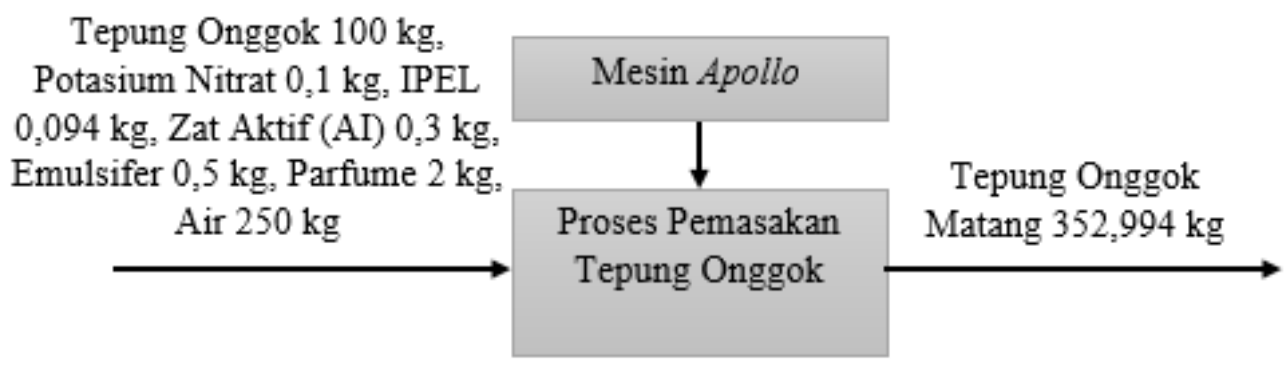

Gambar 5 Proses PemasakanTepung Onggok

Dalam proses pemasakan tepung onggok menjadi onggok matang dihasilkan sebanyak 352,994 $\mathrm{kg}$ setiap sekali masak dalam 4 menit proses pemasakan onggok.

\subsection{Proses Pencampuran Bahan Menjadi Adonan Obat Nyamuk}

Berikut merupakanBerikut merupakan perhitungan Material Balance pada proses pencampuran bahan menjadi adonan obat nyamuk :

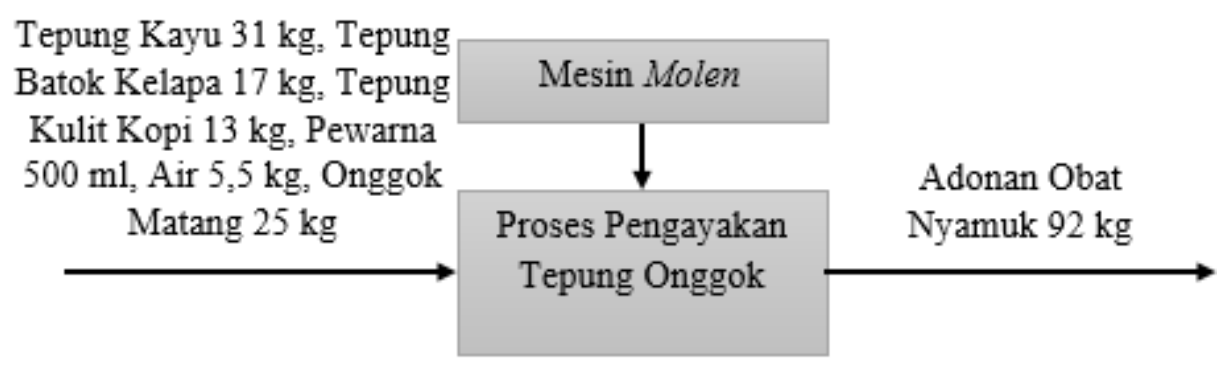

Gambar 6 Proses Pencampuran Bahan Menjadi Adonan Obat Nyamuk

\subsection{Proses Penghancuran Adonan Obat Nyamuk}

Berikut merupakan perhitungan Material Balance pada proses penghancuranadonan obat nyamuk dari mesin Molen menggunakan screw:

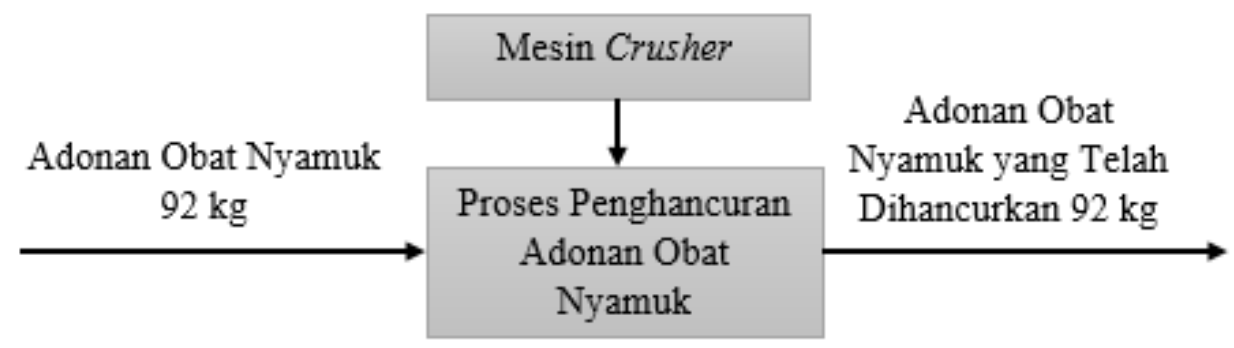

Gambar 7 Proses Penghancuran Adonan Obat Nyamuk

\subsection{Proses Membentuk Lempengan Pasta}

Berikut merupakanBerikut merupakan perhitungan Material Balance pada proses pembentukan adonan obat nyamuk menjadi lempengan pasta : 


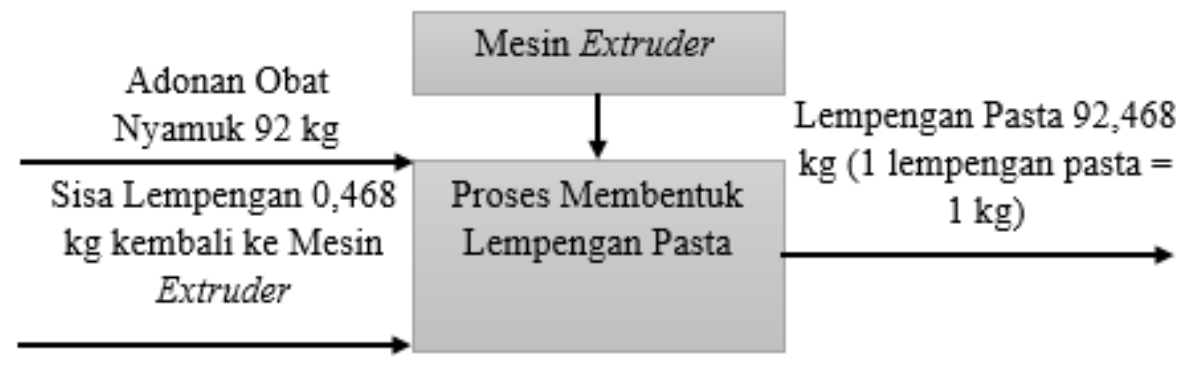

Gambar 8 Proses membentuk Lempengan Pasta

Dalam proses pembentukan adonan menjadi lempengan pasta terdapat tambahan dari sisa mesin Stamping sebanyak $0,468 \mathrm{~kg}$ adonan yang dibawa menggunakan conveyor.

\subsection{Proses Mencetak Lempengan Pasta Menjadi Double Coil Basah}

Berikut merupakanBerikut merupakan perhitungan Material Balance pada proses pencetakan lempengan pasta menjadi double coil basah :

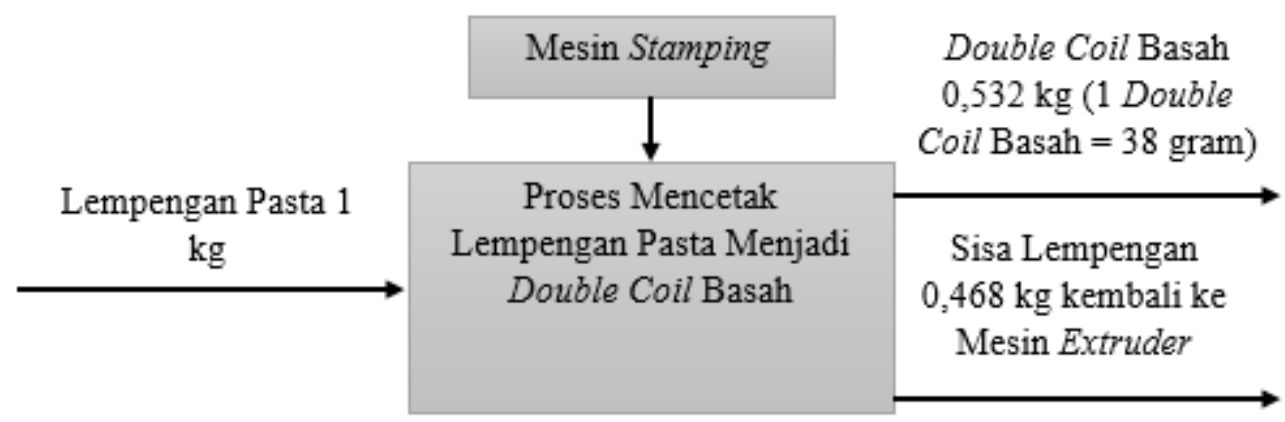

Gambar 9 Proses Mencetak Lempengan Pasta Menjadi Double Coil Basah

Dalam proses mencetak double coil basah setiap sekali mencetak menghasilkan 14 cetakan sebanyak $1 \mathrm{~kg}$ dengan sisa lempengan $0,468 \mathrm{~kg}$ yang kemudian sisa tersebut dibawa menggunakan conveyor menuju mesin Extruder untuk dibentuk kembali menjadi lempengan sehingga dapat dicetak kembali.

\subsection{Proses Pengeringan Double Coil Basah}

Berikut merupakan perhitungan Material Balance pada proses pengeringan double coil basah menjadi double coil kering ada dua, yaitu:

1. Oven Room

Proses pengeringan atau pengurangan kadar air pada double coil basah dengan menggunakan panas dari api. 


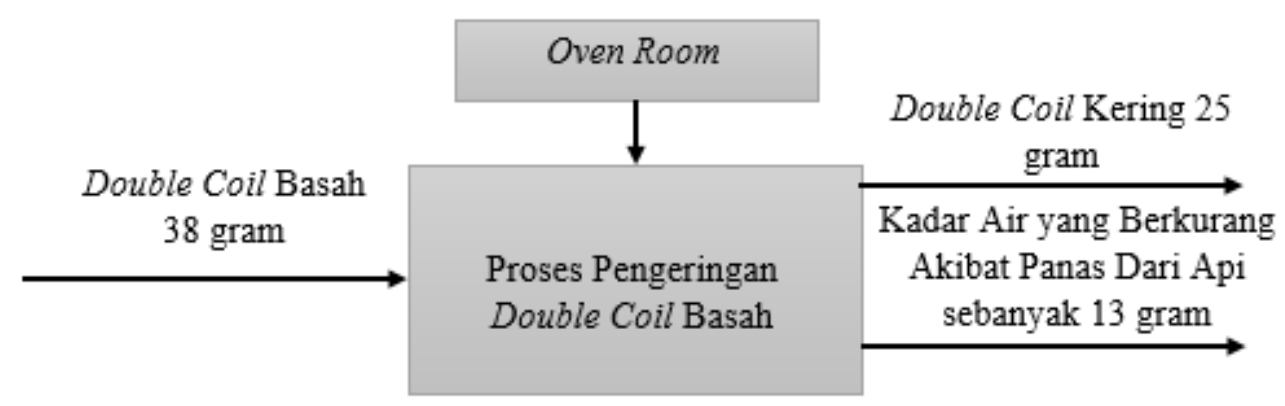

Gambar 10 Proses Pengeringan Double Coil Basah Oven Room

2. Oven Tunel

Proses pengeringan dan pengurangan kadar air pada double coil basah menggunakan panas dari uap air panas dari boyler.

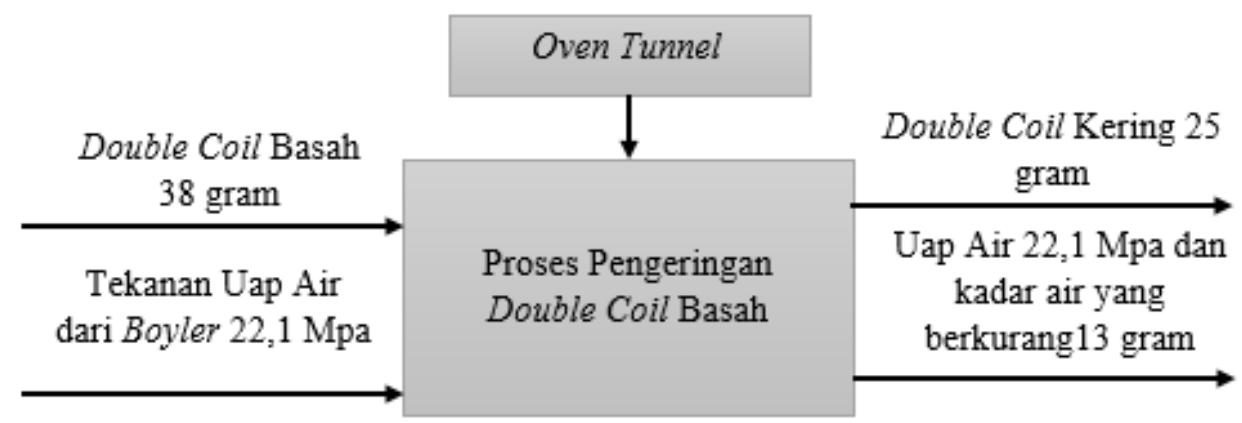

Gambar 11 Proses Pengeringan Double Coil Basah Oven Tunnel

Dalam proses pengurangan kadar air pada double coil basah berkurang sebanyak 13 gram dalam 1 double coil basah.

\subsection{Proses Penyusunan dan Pemisahan Loyang dengan Double Coil Kering}

Berikut merupakan Berikut merupakan perhitungan Material Balance pada proses penyusunan dan pemisahan double coil kering dari loyang :

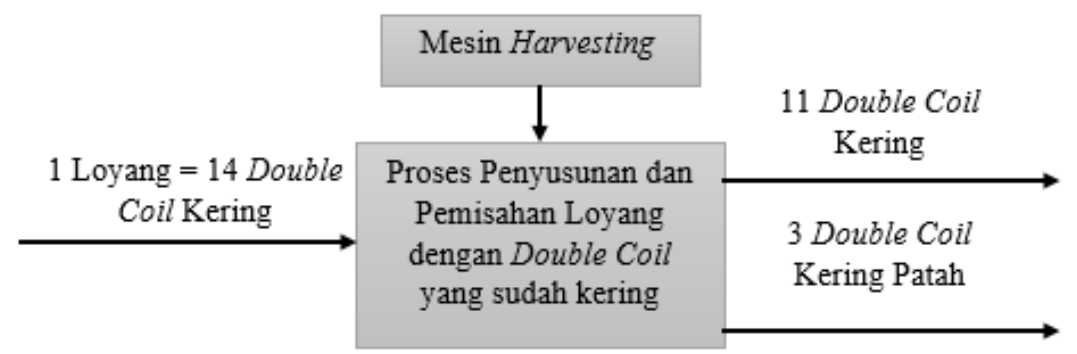

Gambar 12 Proses Penyusunan dan Pemisahan Loyang dengan Double Coil Kering

Dalam proses ini ada sebanyak 3 double coil kering yang patah dalam 1 loyang, dan patahan tersebut di digiling lagi di mesin crushing untuk di haluskan menjadi tepung sehingga dapat digunakan kembali untuk pembuatan obat nyamuk bakar. 


\subsection{Proses Menggiling Double Coil Kering yang Patah}

Berikut merupakanBerikut merupakan perhitungan Material Balance pada proses menggiling double coil kering yang patah dari mesin harvesting:

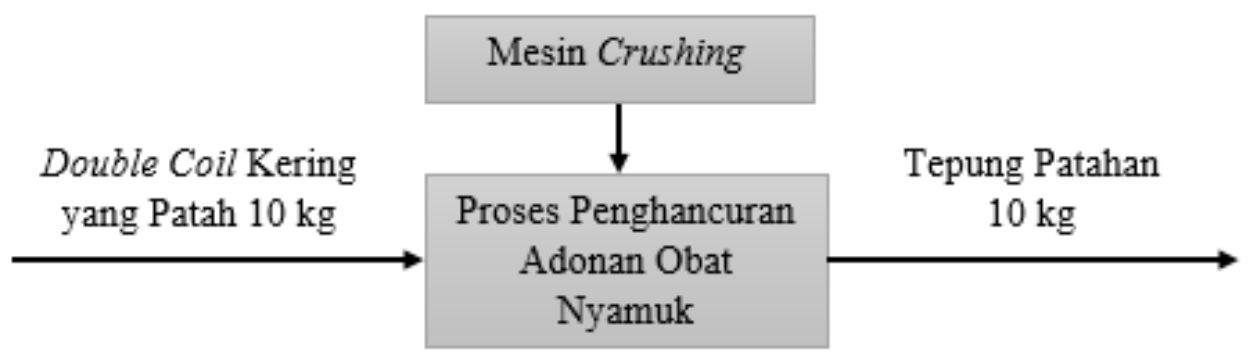

Gambar 13 Proses Menggiling Double Coil Kering yang Patah

\subsection{Proses Mengayak Tepung Sapuan yang Jatuh Di Lantai}

Berikut merupakan perhitungan Material Balance pada proses mengayak tepung sapuan yang jatuh di lantai:

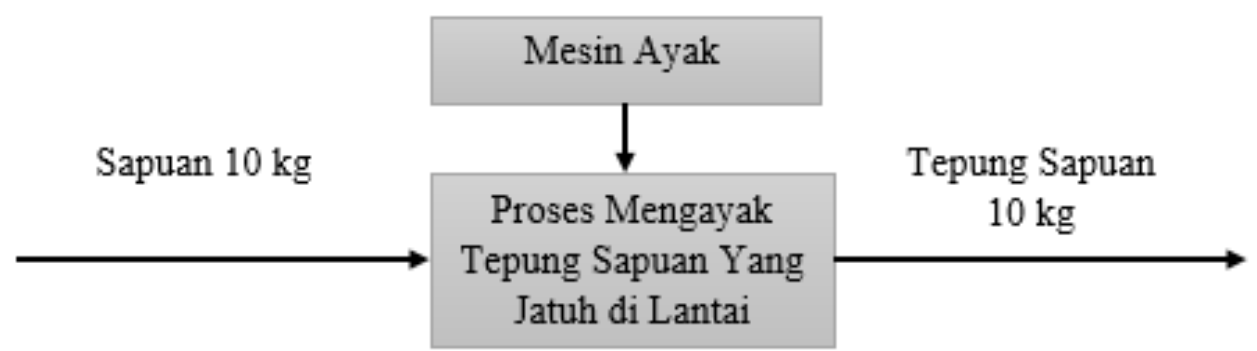

Gambar 14 Proses Mengayak tepung Sapuan yang Jatuh di Lantai

Untuk dapat menganalisa laju limbah dapat digunakan material flow analysis (MFA). Material flow analysis adalah metode yang cocok untuk mendukung pengambilan keputusan dalam pengelolaan limbah dan sumber daya. Dengan menerapkan metode MFA dapat memahami jalur, stok, dan aliran material [6]. MFA dapat digunakan untuk menganalisis transformation, transportation ataupun storage material dalam suatu sistem. MFA menjadi sebuah metode yang komprehensif sebagai alat pengambil keputusan [7] [8].

\section{Kesimpulan dan Saran}

Kesimpulan yang diperoleh berdasarkan hasil penelitian yaitu diketahui strategi dalam minimisasi limbah pada proses produksi obat nyamuk bakar, antara lain : 
1. Sebanyak $1 \mathrm{~kg}$ tepung batok kelapa dapat digunakan lagi sebagai bahan pembuatan obat nyamuk dengan mengumpulkan lalu mengayak kembali tepung tersebut menggunakan mesin ayak.

2. Sebanyak1 $\mathrm{kg}$ tepung kulit kopi dapat digunakan lagi sebagai bahan pembuatan obat nyamuk dengan mengayak kembali tepung tersebut menggunakan mesin ayak.

3. Sebanyak $1 \mathrm{~kg}$ tepung kayu dapat digunakan kembali sebagai bahan pembuatan obat nyamuk dengan mengayak kembali tepung tersebut menggunakan mesin ayak.

4. Sebanyak $1,5 \mathrm{~kg}$ tepung onggok dapat digunakan lagi sebagai bahan pembuatan obat nyamuk dengan mengayak kembali tepung tersebut dengan mesin ayak.

5. Dalam proses mencetak double coil basah setiap sekali mencetak menghasilkan 14 cetakan sebanyak $1 \mathrm{~kg}$ dengan sisa lempengan 0,468 $\mathrm{kg}$ yang kemudian sisa tersebut dibawa menggunakan conveyor menuju mesin Extruder untuk dibentuk kembali menjadi lempengan sehingga dapat dicetak kembali.

6. Dalam proses ini ada sebanyak 3 double coil kering yang patah dalam 1 loyang, dan patahan tersebut di digiling lagi di mesin crushing untuk di haluskan menjadi tepung sehingga dapat digunakan kembali untuk pembuatan obat nyamuk bakar.

Saran untuk penelitian ini yaitu dari hasil penelitian diketahui bahwa ada beberapa material yang dapat digunakan kembali dalam proses produksi selanjutnya dengan menggunakan material hasil limbah yang masih dapat diolah kembali dari proses produksi sebelumnya.

\section{REFERENCES}

[1] Muhammad, Anwar, Adriana. (2014). Upaya Peningkatan Produktivitas Kinerja Lingkungan dengan Pendekatan Green Productivity pada Pabrik Kelapa Sawit PT. Mopoli Raya. Malikussaleh Industrial Engineering Journal. Vol. 3 No. 2: 10-15.

[2] Yasa, M. (2010). Ekonomi Hijau, Produksi Bersih dan Ekonomi Kreatif: Pendekatan Mencegahan Resiko Lingkungan Menuju Pertumbuhan Ekonomi Berkualitas di Provinsi Bali. Jurnal Bumi Lestari . Vol. 10 No. 2: 285-294.

[3] Ramadani, B, Komar S, Ningsih Y B. (2017). Evaluasi Kinerja Unit Crushing Plant pada Tambang Andesit untuk Mencapai Target Produksi 8000 Ton/Bulan pada Bulan Mei 2016 di PT. Ansar Terang Crushindo Kabupaten Limapuluh Kota Sumatera Barat. JP . Vol. 1 No. 3.

[4] Argo B D. (2010). Analisis Sistem Proses Pindah Massa pada Ekstraksi Secara Mekanik Minyak Kedelai (Glycine Max Oil). Jurnal Keteknikan Pertanian. Vol. 24 No. 2: 101-106. 
[5] Sinulingga, Sukaria. (2011). Metodologi Penelitian. USU PRESS

[6] Thaheer, H, Hasibuan S. (2014). Analisis Keseimbangan BahanPada Kaji Awal Lingkungan Perencanaan Sistem Manajemen Lingkungan ISO 14001:2004 Industri Minuman Sari Buah. Prosiding Seminar Nasional IDEC 2014.

[7] Rimantho, D, Noor E, Eriyatno, Efendi H. (2019). Penilaian Aliran Limbah Elektronika di DKI Jakarta Menggunakan Material Flow Analysis (MFA). Jurnal Ilmu Lingkungan. Vol. 17 No. 1: 120-129.

[8] Allesch A, Brunner P H. (2015). Material Flow Analysis as a Decision Support Tool for Waste Management: A Literature Review. Journal of Industrial Ecology. Vol. 19 No. 5: 753-764. 